\title{
PŘIROZENÁ RADIOAKTIVITA KRYSTALINIKA, PALEOZOICKÝCH SEDIMENTÁRNÍCH HORNIN A VYBRANÝCH KENOZOICKÝCH SEDIMENTŮ NA MAPOVÉM LISTU 24-22 OLOMOUC
}

\author{
Natural radioactivity of crystalline rocks, Palaeozoic sedimentary rocks and selected \\ Cenozoic sediments on the map sheet 24-22 Olomouc
}

\author{
Jiří Zimák \\ Katedra geologie PřF UP, tř. 17. listopadu 12, 77146 Olomouc; e-mail:jiri.zimak@upol.cz
}

(24-22 Olomouc)

Key words: Brunovistulicum, Palaeozoic flysch formations, Tertiary marine sediments, fluvial sediments, loess, gamma-spectrometry

\begin{abstract}
The paper deals with natural radioactivity of crystalline rocks, Palaeozoic sedimentary rocks and selected Cenozoic sediments on the map sheet 24-22 Olomouc. Studied rocks belong to following geological units: the Brunovistulicum (Proterozoic granitoids and dioritoids, often mylonitized), the Moravo-Silesian Palaeozoic (mainly carbonate rocks of the Macocha and Líšen Fms. and flysch sediments of the Andělská Hora, Protivanov, Horní Benešov, Rozstání, Moravice and Myslejovice Fms.), the Carpathian Foredeep (Miocene marine sands and clays) and the Upper Morava Basin (Pliocene-Pleistocene lacustrine and fluvial sediments and loesses). Contents of potassium, uranium and thorium were measured using a laboratory gamma-ray spectrometer in 612 rock samples. Data are tabled and discussed. From calculated values of mass activity of ${ }^{226} \mathrm{Ra}$ equivalent $\left(a_{m}\right)$ it is evident that natural radioactivity of the studied rocks is predominantly low. Slightly increased $a_{m}$ values were found in silty shales, clay shales and siltstones of the Rozstáni $\mathrm{Fm}$. (189 Bq. $\mathrm{kg}^{-1}$ on average, $308 \mathrm{~Bq} \cdot \mathrm{kg}^{-1}$ in the sample with the highest natural radioactivity).
\end{abstract}

Úvod

Jedním ze základních fyzikálních parametrů přírodního prostředí je jeho přirozená radioaktivita. Tento článek hodnotí radioaktivitu krystalinika, paleozoických sedimentárních hornin a vybraných kenozoických sedimentů na mapovém listu 24-22 Olomouc. Vychází $\mathrm{z}$ obsahů hlavních přirozených radioaktivních prvků (K, U a Th) stanovených laboratorní gamaspektrometrií $\mathrm{v}$ reprezentativních souborech hornin.

\section{Geologické jednotky a jejich horninová náplň}

Nejstaršími horninami vystupujícími na mapovém listu 24-22 Olomouc jsou kataklázou silně postižené granodiority a diority s žilným doprovodem (pegmatity), řazené $\mathrm{k}$ brunovistuliku (např. Břízová et al. 2000). Na brunovistuliku je uloženo moravskoslezské paleozoikum. Jeho zde nejstarším doloženým členem jsou devonská bazální klastika (křemenné pískovce až slepence), stratigraficky výše jsou karbonátové horniny macošského a líšeňského souvrství. Devonská karbonátová sedimentace směrem do nadloží přechází do ukládání siliciklastik (devon až spodní karbon), která mají charakter flyše, tvořeného střídáním psefitů (převažují gravelity), psamitů (droby, arkózové pískovce, křemenné pískovce) a hornin strukturně odpovídajících aleuritům a pelitům (siltovce, siltové břidlice, jílové břidlice, časté jsou laminity). Flyšové sedimenty na sledovaném mapovém listu náleží $\mathrm{k}$ šesti různým souvrstvím: andělskohorskému, protivanovskému, hornobenešovskému, rozstáňskému, moravickému a myslejovickému (Růžička et al. 1995).

Krystalinikum a moravskoslezské paleozoikum je na většině plochy listu překryto kenozoickými sedimenty.
Jde o miocenní sedimenty karpatské předhlubně (vápnité jíly a písky), pliocenní lakustrinní a fluviální sedimenty (písky, jíly, silty a štěrky - tzv. „pestrý pliocén) a kvarterní uloženiny (hlavně fluviální a fluviolimnické písky, štěrky a jíly a také spraše) - viz Růžička et al. (1995).

\section{Vzorky a metody}

Na mapovém listu 24-22 Olomouc bylo na 286 lokalitách odebráno 612 vzorků reprezentujících všechny horninové typy brunovistulika a moravskoslezského paleozoika a vybrané typy kenozoických sedimentů. Determinace hornin byla prováděna jen makroskopicky, což působilo komplikace pouze $\mathrm{v}$ př́ípadě brunovistulických plutonitů. Nutno však poznamenat, že ani studium těchto hornin ve výbrusech nemusí vést k jednoznačnému stanovení jejich původní povahy (jsou-li mylonitizovány).

V horninových vzorcích byly na PřF UP v Olomouci za použití spektrometru SG - $1000 \mathrm{LAB} \mathrm{s} \mathrm{NaI(Tl)} \mathrm{detek-}$ torem o objemu $0,35 \mathrm{dm}^{3}$ (průměr $76 \mathrm{~mm}$, délka $76 \mathrm{~mm}$ ) stanoveny obsahy $\mathrm{K}$ (př́mo na základě koncentrace ${ }^{40} \mathrm{~K}$ ), U a Th (na základě dceřiných produktů, a proto jsou jejich obsahy při uvádění výsledků analýz označovány jako eU a eTh). Meze detekce: $\mathrm{K}=0,5 \mathrm{hm} . \%, \mathrm{U}$ a $\mathrm{Th}=1,5 \mathrm{ppm})$. Při výpočtu hodnot $\mathrm{a}_{\mathrm{m}}$ a $\mathrm{D}$ (viz níže) a při statistickém zpracování dat byly obsahy K pod mezí detekce nahrazeny hodnotou $0,33 \mathrm{hm}$. \%, obdobně v prípadě U a Th hodnotou $1 \mathrm{ppm}$. Před měřením byly horninové vzorky rozdrceny a uzavřeny do krabiček o objemu $250 \mathrm{ml}$, v nichž byly následně měřeny. Hmotnost takto připravených vzorků se pohybovala kolem 400 gramů.

Přirozená radioaktivita hornin je hodnocena na základě hmotnostní aktivity ekvivalentu ${ }^{226} \mathrm{Ra}\left(\mathrm{a}_{\mathrm{m}}\right)$ a též 


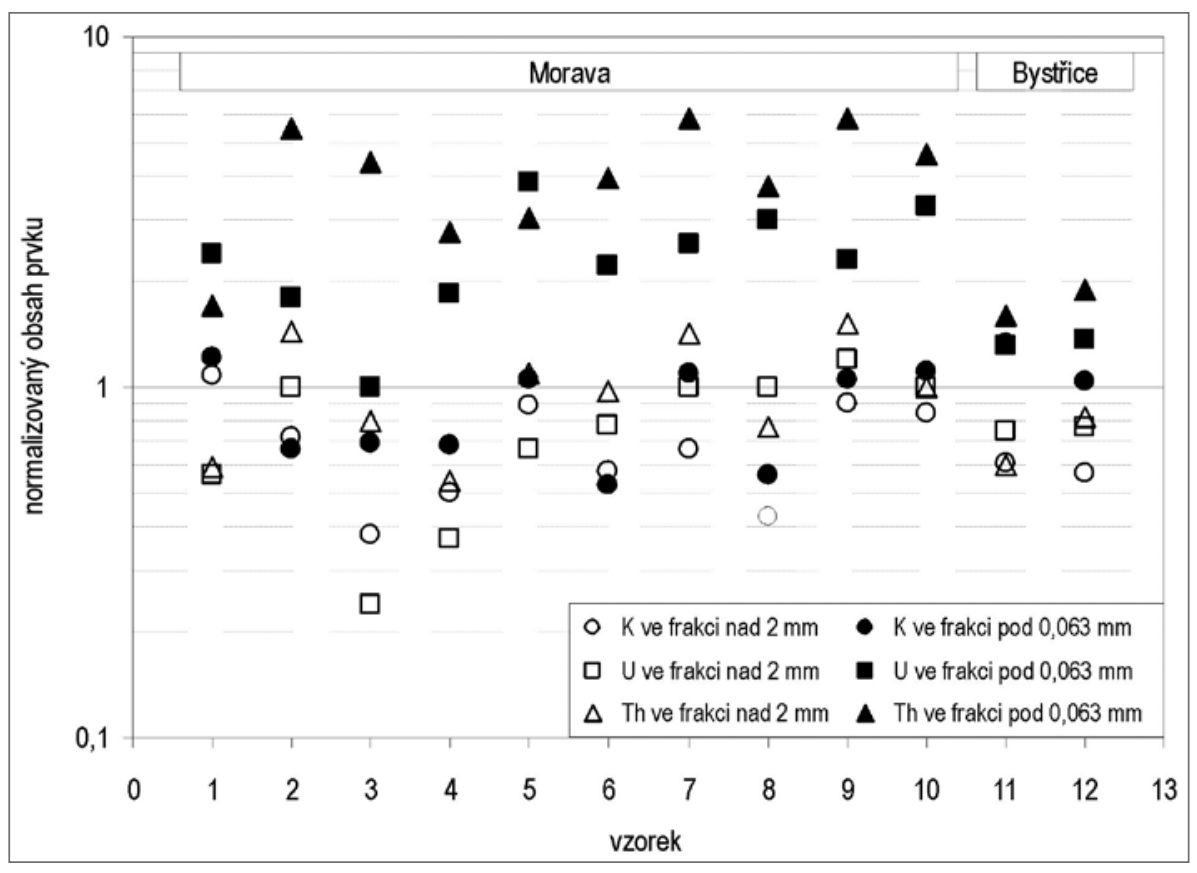

Obr. 1: Obsahy přirozených radioaktivních prvků v zrnitostních frakcích nad $2 \mathrm{~mm}$ a pod $0,063 \mathrm{~mm}$ kvarterních fluviálních sedimentů, normalizované na obsahy těchto prvků v zrnitostní frakci 0,063 až $2 \mathrm{~mm}$.

Fig. 1: Contents of the natural radioactive elements in grain fractions over $2 \mathrm{~mm}$ and below $0.063 \mathrm{~mm}$ of the Quaternary fluvial sediments, normalized on contents of the elements in a grain fraction 0.063 to $2 \mathrm{~mm}$.

Tab. 1: Obsahy přirozených radioaktivních prvků $(K, U, T h)$ v proterozoických a paleozoických horninách, vypočtené hodnoty hmotnostní aktivity ekvivalentu ${ }^{226} \mathrm{Ra}\left(\mathrm{a}_{\mathrm{m}}\right) ; \mathrm{n}=$ počet vzorků, $\mathrm{x}=$ průměr.

Tab. 1: Contents of the natural radioactive elements $(K, U, T h)$ in Proterozoic and Palaeozoic rocks, calculated mass activity of ${ }^{226} \mathrm{Ra}$ equivalent $\left(\mathrm{a}_{\mathrm{m}}\right) ; \mathrm{n}=$ number of samples, $\mathrm{x}=$ average.

\begin{tabular}{|c|c|c|c|c|c|c|c|c|c|c|c|c|c|c|c|c|c|}
\hline \multirow{2}{*}{ geol. jednotka/hornina } & \multirow{2}{*}{$\mathrm{n}$} & \multicolumn{4}{|c|}{$\mathrm{K}(\mathrm{hm} . \%)$} & \multicolumn{4}{|c|}{$\mathrm{eU}(\mathrm{ppm})$} & \multicolumn{4}{|c|}{ eTh (ppm) } & \multicolumn{4}{|c|}{$a_{m}\left(B q \cdot k^{-1}\right)$} \\
\hline & & $\min$. & $\max$. & med. & $\mathrm{x}$ & $\min$. & max. & med. & $\mathrm{x}$ & $\min$. & max. & med. & $\mathrm{x}$ & $\min$. & $\max$. & med. & $\mathrm{x}$ \\
\hline \multicolumn{18}{|l|}{ brunovistulikum } \\
\hline granitoid & 4 & 2,2 & 3,7 & 2,8 & 2,9 & $<1,5$ & 2,9 & 1,8 & 1,9 & 5,6 & 10,7 & 8,5 & 8,3 & 126 & 155 & 141 & 141 \\
\hline dioritoid & 7 & 2,2 & 3,7 & 2,8 & 2,9 & $<1,5$ & $<1,5$ & $<1,5$ & $<1,5$ & 3,2 & 15,3 & 6,2 & 7,3 & 84 & 190 & 118 & 124 \\
\hline pegmatit & 2 & 3,5 & 4,9 & 4,2 & 4,2 & $<1,5$ & $<1,5$ & $<1,5$ & $<1,5$ & $<1,5$ & 1,9 & $<1,5$ & $<1,5$ & 103 & 141 & 122 & 122 \\
\hline \multicolumn{18}{|l|}{ bazální klastika devonu } \\
\hline pískovec, slepenec & 5 & $<0,5$ & 2,7 & $<0,5$ & 0,8 & $<1,5$ & 4,2 & $\mid<1,5$ & 1,6 & $<1,5$ & 11,0 & $<1,5$ & 3,2 & 26 & 181 & 26 & 58 \\
\hline \multicolumn{18}{|c|}{ macošské souvrství (MS) a lišeňské souvrství (LS) } \\
\hline vápenec - MS & 63 & $<0,5$ & $<0,5$ & $<0,5$ & $<0,5$ & $<1,5$ & 2,6 & $<1,5$ & $<1,5$ & $<1,5$ & $<1,5$ & $<1,5$ & $<1,5$ & 26 & 46 & 26 & 28 \\
\hline vápenec - LS & 2 & $<0,5$ & $<0,5$ & $<0,5$ & $<0,5$ & $<1,5$ & $<1,5$ & $<1,5$ & $<1,5$ & $<1,5$ & $<1,5$ & $<1,5$ & $<1,5$ & 26 & 26 & 26 & 26 \\
\hline siliciklastika - LS & 2 & $<0,5$ & 0,6 & $<0,5$ & $<0,5$ & $<1,5$ & $<1,5$ & $<1,5$ & $<1,5$ & 2,4 & 2,8 & 2,6 & 2,6 & 40 & 43 & 42 & 42 \\
\hline \multicolumn{18}{|l|}{ andělskohorské souvrství } \\
\hline psamity & 21 & 1,0 & 2,5 & 1,9 & 1,8 & 1,6 & 4,9 & 2,6 & 2,8 & 7,0 & 17,3 & 10,3 & 10,9 & 104 & 192 & 141 & 142 \\
\hline aleurity a pelity & 14 & 1,4 & 3,0 & 2,5 & 2,3 & 1,7 & 7,2 & 2,6 & 2,9 & 8,7 & 15,8 & 12,0 & 11,8 & 115 & 218 & 154 & 158 \\
\hline \multicolumn{18}{|l|}{ protivanovské souvrství } \\
\hline psamity & 8 & 1,1 & 2,2 & 1,4 & 1,6 & $<1,5$ & 3,4 & 1,6 & 1,8 & 8,7 & 12,3 & 10,0 & 10,1 & 97 & 156 & 113 & 118 \\
\hline aleurity a pelity & 7 & 2,1 & 2,5 & 2,3 & 2,3 & $<1,5$ & 3,1 & 1,7 & 2,0 & 8,6 & 11,7 & 11,2 & 10,9 & 113 & 157 & 145 & 142 \\
\hline \multicolumn{18}{|l|}{ hornobenešovské souvrství } \\
\hline psamity & 33 & 0,9 & 2,6 & 1,6 & 1,7 & $<1,5$ & 3,6 & 2,5 & 2,4 & 7,2 & 15,6 & 10,4 & 10,4 & 88 & 175 & 129 & 132 \\
\hline aleurity a pelity & 5 & 2,0 & 2,6 & 2,4 & 2,3 & 2,2 & 4,2 & 3,3 & 3,2 & 10,3 & 14,2 & 12,6 & 12,2 & 150 & 192 & 162 & 167 \\
\hline \multicolumn{18}{|l|}{ rozstáňské souvrství } \\
\hline psefity & 11 & 0,8 & 2,8 & 1,8 & 1,9 & $<1,5$ & 5,6 & 2,0 & 2,3 & 3,6 & 14,4 & 9,1 & 9,8 & 53 & 218 & 120 & 130 \\
\hline psamity & 59 & 0,8 & 2,8 & 2,0 & 1,9 & $<1,5$ & 7,2 & 1,8 & 2,0 & 4,2 & 22,2 & 10,5 & 10,6 & 56 & 272 & 129 & 132 \\
\hline aleurity a pelity & 20 & 2,0 & 3,4 & 2,9 & 2,8 & 1,6 & 7,4 & 2,8 & 3,5 & 10,2 & 24,4 & 12,5 & 13,5 & 142 & 308 & 176 & 189 \\
\hline \multicolumn{18}{|l|}{ moravické souvrství } \\
\hline psefity & 12 & 1,6 & 2,3 & 1,9 & 1,9 & $<1,5$ & 3,3 & 2,1 & 2,1 & 5,9 & 10,9 & 8,2 & 8,3 & 95 & 177 & 119 & 120 \\
\hline psamity & 19 & 1,1 & 3,0 & 1,8 & 1,8 & $<1,5$ & 2,2 & $<1,5$ & $<1,5$ & 6,8 & 14,1 & 9,9 & 10,2 & 85 & 177 & 121 & 120 \\
\hline aleurity a pelity & 12 & 1,9 & 3,6 & 2,5 & 2,6 & 1,5 & 2,6 & 2,0 & 2,0 & 8,7 & 15,1 & 11,0 & 11,3 & 115 & 194 & 149 & 153 \\
\hline \multicolumn{18}{|l|}{ myslejovické souvrství } \\
\hline psefity & 17 & 1,0 & 2,3 & 1,5 & 1,6 & $<1,5$ & 2,4 & 1,5 & 1,6 & 5,8 & 8,7 & 7,3 & 7,3 & 80 & 118 & 101 & 100 \\
\hline psamity & 55 & 1,0 & 3,3 & 1,9 & 1,9 & $<1,5$ & 3,1 & 1,8 & 1,9 & 6,8 & 13,0 & 9,6 & 9,6 & 85 & 169 & 124 & 125 \\
\hline aleurity a pelity & 84 & 1,3 & 3,1 & 2,5 & 2,4 & $<1,5$ & 3,5 & 2,3 & 2,3 & 8,3 & 14,5 & 11,4 & 11,4 & 92 & 197 & 153 & 153 \\
\hline
\end{tabular}


Tab. 2: Obsahy přirozených radioaktivních prvků (K, U, Th) v kenozoických sedimentech, vypočtené hodnoty hmotnostní aktivity ekvivalentu ${ }^{226} \mathrm{Ra}\left(\mathrm{a}_{\mathrm{m}}\right) ; \mathrm{n}=$ počet vzorků, $\mathrm{x}=$ průměr.

Tab. 2: Contents of the natural radioactive elements (K, U, Th) in Cenozoic sediments, calculated mass activity of ${ }^{226}$ Ra equivalent $\left(\mathrm{a}_{\mathrm{m}}\right) ; \mathrm{n}=$ number of samples, $\mathrm{x}=$ average.

\begin{tabular}{|c|c|c|c|c|c|c|c|c|c|c|c|c|c|c|c|c|c|}
\hline \multirow{2}{*}{ geol. jednotka/hornina } & \multirow{2}{*}{$\mathrm{n}$} & \multicolumn{4}{|c|}{$\mathrm{K}(\mathrm{hm} . \%)$} & \multicolumn{4}{|c|}{ eU (ppm) } & \multicolumn{4}{|c|}{ eTh (ppm) } & \multicolumn{4}{|c|}{$\mathrm{a}_{\mathrm{m}}\left(\mathrm{Bq} \cdot \mathrm{kg}^{-1}\right)$} \\
\hline & & $\min$. & $\max$. & med. & $\mathrm{x}$ & $\min$. & $\max$. & med. & $\mathrm{x}$ & $\min$. & $\max$. & med. & $\mathrm{x}$ & $\min$. & $\max$. & med. & $\mathrm{x}$ \\
\hline \multicolumn{18}{|c|}{ karpatská předhlubeň - miocenní marinní sedimenty } \\
\hline písek & 2 & 1,2 & 1,7 & 1,5 & 1,5 & $<1,5$ & $<1,5$ & $<1,5$ & $<1,5$ & 1,8 & 5,3 & 3,6 & 3,6 & 64 & 72 & 68 & 68 \\
\hline jíl & 6 & 1,9 & 2,2 & 2,2 & 2,1 & $<1,5$ & 2,2 & 1,8 & 1,8 & 6,6 & 11,8 & 9,6 & 9,3 & 99 & 149 & 129 & 125 \\
\hline \multicolumn{18}{|c|}{ Hornomoravský úval - pliocenní fluviální a lakustrinní sedimenty } \\
\hline štěrk & 3 & $<0,5$ & 1,1 & $<0,5$ & 0,6 & $<1,5$ & $<1,5$ & $<1,5$ & $<1,5$ & 3,4 & 4,0 & 3,6 & 3,7 & 41 & 62 & 41 & 48 \\
\hline písek & 13 & $<0,5$ & 1,7 & 0,8 & 0,9 & $<1,5$ & 2,7 & $<1,5$ & $<1,5$ & 1,6 & 10,7 & 2,9 & 4,5 & 30 & 124 & 46 & 63 \\
\hline silt a jíl & 30 & $<0,5$ & 2,1 & 1,7 & 1,6 & $<1,5$ & 3,1 & 1,8 & 1,8 & 5,6 & 12,2 & 8,7 & 8,6 & 67 & 143 & 112 & 110 \\
\hline \multicolumn{18}{|c|}{ Hornomoravský úval - kvarterni fluviální sedimenty a spraše } \\
\hline štěrk & 37 & 1,3 & 2,1 & 1,6 & 1,6 & $<1,5$ & 3,0 & 1,6 & 1,7 & 2,2 & 11,3 & 5,6 & 6,3 & 56 & 144 & 87 & 96 \\
\hline písek & 32 & 1,0 & 2,3 & 1,7 & 1,7 & $<1,5$ & $<1,5$ & $<1,5$ & $<1,5$ & 3,4 & 10,3 & 4,4 & 5,5 & 56 & 139 & 82 & 89 \\
\hline jíl & 7 & 1,5 & 2,1 & 1,6 & 1,7 & 2,0 & 3,1 & 2,6 & 2,6 & 8,3 & 12,0 & 9,5 & 9,6 & 111 & 145 & 128 & 128 \\
\hline spraš & 20 & 1,3 & 1,8 & 1,6 & 1,6 & 2,4 & 3,1 & 3,0 & 2,9 & 10,3 & 11,9 & 11,0 & 11,0 & 121 & 150 & 141 & 139 \\
\hline
\end{tabular}

dávkového př́ikonu záření gama terestrického původu (D). Tyto parametry byly $\mathrm{z}$ výsledků gamaspektrometrických analýz vypočteny pomocí vztahů $\mathrm{a}_{\mathrm{m}}\left[\mathrm{Bq} \cdot \mathrm{kg}^{-1}\right]=$ $(0,077 \times 313 \mathrm{~K})+12,35 \mathrm{U}+(1,43 \times 4,06 \mathrm{Th}), \mathrm{D}\left[\mathrm{nGy} \cdot \mathrm{h}^{-1}\right]$ $=(0,043 \times 313 \mathrm{~K})+(0,427 \times 12,35 \mathrm{U})+(0,662 \times 4,06 \mathrm{Th})$, do nichž je obsah $\mathrm{K}$ dosazován $\mathrm{v}$ hm. \%, obsahy U a Th v ppm (UNSCEAR 1988; Matolín - Chlupáčová 1997; Ngachin et al. 2007).

V kvarterních fluviálních (příp. fluviolimnických) štěrcích a píscích byla sledována přirozená radioaktivita psefitové, psamitové a aleuritové + pelitové frakce. V souboru 12 studovaných štěrků a písků je zastoupeno 10 sedimentů řeky Moravy, odebraných na k. ú. Lhota nad Moravou (vz. 1 v obr. 1), Mezice (vz. 2 až 4), Březce (vz. 5 až 7), Černovír (vz. 8) a Lazce (vz. 9 a 10), zbývající dva vzorky reprezentují sedimenty řeky Bystřice a pochází z k. ú. Bělidla (vz. 11) a k. ú. Chválkovice (vz. 12). Tř̀i výše uvedené frakce byly získány sítováním za sucha. Psefitová a psamitová frakce byly po ukončení sítování přímo na sítech propláchnuty vodou (podsítný materiál byl odstraněn) a následně vysušeny. Sítovaný vzorek byl vždy získán sdružením několika vzorků písku nebo štěrku odebraných na téže lokalitě. Hmotnost sítovaných vzorků se pohybovala v rozpětí zhruba $5 \mathrm{až} 8 \mathrm{~kg}$. I přesto se ve většině prúpadů nepodařilo získat potřebný objem zrnitostní frakce pod 0,063 mm, který by umožnil provedení gamaspektrometrické analýzy standardním způsobem. K analýze byly použity menší objemy aleuritové + pelitové frakce (v jednom př́padě jen asi $35 \mathrm{ml}$ ), přesnost stanovení $\mathrm{K}, \mathrm{U}$ a Th je výrazně nižší (relativně vysoké hodnoty standardní deviace, špatná reprodukovatelnost analýz).

\section{Výsledky}

Výsledky všech laboratorních gamaspektrometrických stanovení obsahů K, U a Th v horninových vzorcích jsou shrnuty v tabulkách 1 a 2 . Zjištěné obsahy $\mathrm{K}, \mathrm{U}$ a Th v jednotlivých zrnitostních frakcích štěrků a písků řeky Moravy a Bystřice byly využity k vytvoření obrázku 1. Významné či zajímavé poznatky jsou komentovány v následující kapitole.

\section{Diskuze}

1. $\mathrm{S}$ jedinou výjimkou průměrná $\mathrm{a}_{\mathrm{m}}$ studovaných hornin nedosahuje hodnot vypočtených pro průměrnou zemskou kůru (kolem $180 \mathrm{~Bq} \cdot \mathrm{kg}^{-1}$ ). Touto výjimkou jsou aleurity a pelity rozstáňského souvrství, jejichž průměrná $a_{m}$ je $189 \mathrm{~Bq} \cdot \mathrm{kg}^{-1}$. Do téže skupiny hornin patř́i i vzorek $\mathrm{s}$ nejvyšší $\mathrm{a}_{\mathrm{m}}$ zjištěnou na listu 24-22 Olomouc: siltovec z k. ú. Měrotín s a 308 Bq. $\mathrm{kg}^{-1}\left(\mathrm{D}=146 \mathrm{nGy} \cdot \mathrm{h}^{-1}\right)$.

2. U všech šesti flyšových souvrství lze konstatovat, že nejvyšší průměrné hodnoty $\mathrm{a}_{\mathrm{m}}$ byly zaznamenány ve skupině aleuritů a pelitů, což souvisí s vyššími průměrnými obsahy K, U a Th v této skupině hornin ve srovnání $\mathrm{s}$ psamity, př́padně i psefity (viz data $\mathrm{v}$ tab. 1). Na růst $\mathrm{a}_{\mathrm{m}}$ ve flyšových sedimentech moravskoslezského paleozoika v řadě psefit - psamit - aleurit + pelit již upozorňuje např. např. Manová - Matolín (1989), Zimák - Štelcl (2004) a Zimák (2012).

3. Velmi výrazný vztah mezi zrnitostí a $\mathrm{a}_{\mathrm{m}}$ byl zjištěn u nezpevněných tercierních sedimentů. Miocenní jíly karpatské předhlubně vykazují přibližně dvojnásobnou $\mathrm{a}_{\mathrm{m}}$ ve srovnání s písky (tab. 2), soubor studovaných vzorků je však velmi malý. Zcela shodný trend byl zaznamenán u reprezentativního souboru pliocenních lakustrinních a fluviálních sedimentů Hornomoravského úvalu (tab. 2).

4. U kvarterních fluviálních sedimentů Hornomoravského úvalu (tab. 2) se trend popsaný v bodě 3 neprojevuje tak výrazně, což může souviset s často špatným zrnitostním vytřríděním těchto sedimentů (běžné jsou např. jílovité štěrky). $Z$ dat v tabulce 2 je zřejmé, že mezi štěrky a písky $\mathrm{v}$ podstatě neexistují rozdíly mezi průměrnými obsahy sledovaných prvků, a proto i průměrné hodnoty $\mathrm{a}_{\mathrm{m}}$ jsou víceméně shodné. Přirozená radioaktivita jílů je o něco vyšší, což je dáno v průměru vyššími obsahy U a Th. Aleuritová a pelitová frakce (tj. frakce pod $0,063 \mathrm{~mm}$ ) štěrků a písků má obvykle vyšší obsahy U a Th než frakce hrubozrnnější, a v některých prrípadech jsou tyto rozdíly velmi výrazné. Obrázek 1 vyjadřuje obsahy K, U a Th v psefitové a aleuritové + pelitové frakci dvanácti vzorků štěrků a písků, a to po normalizaci na obsah těchto prvků v psamitové frakci daného vzorku. Obsahy K, U a Th v psefitové frakci jsou většinou nižší 
než v psamitové frakci. I když údaje o obsazích $\mathrm{K}, \mathrm{U}$ a Th $\mathrm{v}$ aleuritové + pelitové frakci některých vzorků nejsou z výše uvedených důvodů přesné, je z obrázku 1 zřejmé, že v této frakci jsou s výjimkou vzorku 2 vždy zvýšené obsahy U a Th, zatímco obsahy K jsou zhruba stejné nebo nižší (ve srovnání s obsahy těchto prvků v psamitové frakci).

5. Horniny brunovistulika a devonské sedimenty na listu vystupují na jen velmi malých plochách. Jejich relativně nízkou přirozenou radioaktivitu již dříve prokázali Přichystal et al. (2002), Zimák - Štelcl (2007) a Zimák (2011).

6. Gnojek - Šalanský (2000) hodnotí výsledky aeroradiometrie na listu 24-224 Olomouc takto: „většina území, zakrytá kvartérními (pleistocenními) usazeninami, vykazuje koncentrace draslíku okolo 1,5\%, uranu nejčastěji 3, méně často $2 \mathrm{ppm}$ a thoria většinou $8 \mathrm{ppm}$ $\mathrm{s}$ rozpětím 6 až $10 \mathrm{ppm}$ “. V př́padě tohoto území lze konstatovat velmi dobrou shodu mezi výsledky letecké geofyziky a laboratorní gamaspektrometrie (viz data v tab. 2).

\section{Závěr}

Průměrná hmotnostní aktivita ekvivalentu ${ }^{226} \mathrm{Ra} v$ počtená pro horniny brunovistulika, moravskoslezského paleozoika a kenozoické marinní, lakustrinní a fluviální sedimenty a také spraše na listu 24-22 Olomouc většinou nedosahuje hodnot pro průměrnou zemskou kůru, tj. kolem $180 \mathrm{~Bq} \cdot \mathrm{kg}^{-1}$. Uvedenou hodnotu překračují pouze siltové a jílové břidlice a siltovce rozstáňského souvrství (rozpětí 142 až $308 \mathrm{~Bq} \cdot \mathrm{kg}^{-1}$, průměr $189 \mathrm{~Bq} \cdot \mathrm{kg}^{-1}$ ).

\section{Literatura}

Břízová, E. - Čtyroká, J. - Hanžl, P. - Hladilová, Š. - Hrubeš, M. - Novák, Z. - Švábenická, L. - Zapletal, J. (2000): Geologický vývoj a charakteristika jednotek. - In: Hrubeš, M. (ed.): Vysvětlivky k základní geologické mapě České republiky $1: 25$ 000. List 24-224 Olomouc, 8-26. Český geologický ústav, Praha.

Gnojek, I. - Šalanský, K. (2000): Geofyzikální poměry. - In: Hrubeš, M. (ed.): Vysvětlivky k základní geologické mapě České republiky $1: 25$ 000. List 24-224 Olomouc, 26-30. Český geologický ústav, Praha.

Manová, M. - Matolín, M. (1989): Radioaktivita hornin ČSSR. - In: Ibrmajer, J. - Suk, M. et al.: Geofyzikální obraz ČSSR, 196-213. ÚÚG - Academia Praha.

Matolín, M. - Chlupáčová, M. (1997): Radioaktivní vlastnosti hornin. - In: Kobr, M. et al.: Petrofyzika, 109-126. Vydavatelství Karolinum, Praha.

Ngachin, M. - Garavaglia, M. - Giovani, C. - Kwato Njock, M. G. - Nourreddine, A. (2007): Assessment of natural radioactivity and associated radiation hazards in some Cameroonian building materials. - Radiation Measurements, 42, 61-67.

Přichystal, A. - Gnojek, I. - Bednaříková, S. (2002): Výsledky gama-spektrometrického studia krystalinika Hornomoravského úvalu. - Geologické výzkumy na Moravě a ve Slezsku v roce 2001, 75-78.

Rủžička, M. - Hrubeš, M. - Dvořák, J. (1995): Geologická mapa ČR 1 : 50 000. List 24-22 Olomouc. Český geologický ústav.

UNSCEAR, United Nations Scientific Committee on the Effects of Atomic Radiation (1988): Exposures from natural sources of radiation. Report to the General Assembly. U. N., New York, USA.

Zimák, J. (2011): Přirozená radioaktivita granitoidů a metagranitoidů brunovistulického teránu na území České republiky. Geologické výzkumy na Moravě a ve Slezsku, 18, 2, 201-204.

Zimák, J. (2012): Přirozená radioaktivita kulmských sedimentů na východním okraji Českého masivu. - Geologické výzkumy na Moravě a ve Slezsku, 19, 1-2, 130-133.

Zimák, J. - Štelcl, J. (2004): Přirozená radioaktivita hornin moravskoslezského kulmu v oblasti Nízkého Jeseníku a Oderských vrchů: příspěvek k poznání zdrojové oblasti klastického materiálu. - Geologické výzkumy na Moravě a ve Slezsku v roce 2003, 11, 103-106.

Zimák, J. - Štelcl, J. (2007): Přirozená radioaktivita paleozoických karbonátových hornin východního okraje Českého masivu. Současnost a perspektiva těžby a úpravy nerudních surovin IV, 131-136. VŠB-TU Ostrava. 